\title{
Dose estimation in the recycling of removed soil for land reclamation
}

\author{
Asako SHIMADA*, Hiromi NEMOTO*, Takuma SAWAGUCHI* and Seiji TAKEDA* \\ *Japan Atomic Energy Agency \\ 2-4 Tokai-mura, Naka-gun, Ibaraki 319-1195, Japan \\ E-mail: shimada.asako@jaea.go.jp
}

Received: 1 November 2019; Revised: 11 March 2020; Accepted: 22 April 2020

\begin{abstract}
Dose estimation for workers and the public was conducted to use the recycled soil removed from the Fukushima prefecture for land reclamation. The land was availed to the public as a greenery-covered area. In the case of revegetation with trees, the absorption of Cs by the trees was considered. The exposure from trees, trimmed or thinned trees, and the organic deposits from litter fall were evaluated. From the results, the concentration levels of radiocesium, ${ }^{134} \mathrm{Cs}$ and ${ }^{137} \mathrm{Cs}$, for which the annual effective exposure dose does not exceed $1 \mathrm{mSv} / \mathrm{y}$ was calculated. Moreover, the thickness of the cover soil required to maintain the exposure dose lower than $10 \mu \mathrm{Sv} / \mathrm{y}$ for the public during servicing was ascertained. Furthermore, disasters were considered; for instance, by considering that tsunamis, fires, and intense heavy rain can increase the exposure doses based on the changes in the conditions of the reclamation land. We confirmed that the additional exposure dose during the disaster and rehabilitation of the area was lower than $1 \mathrm{mSv} / \mathrm{y}$. From these evaluation results, we determined the amenable concentration levels for recycling.
\end{abstract}

Keywords : Accident at the Fukushima Daiichi Nuclear Power Station, Dose estimation, Removed soil, Recycling, Land reclamation

\section{Introduction}

After the Fukushima Daiichi Nuclear Power Station (FDNPS) accident in 2011, a large area of Japan was contaminated by radiocesium. A large quantity of contaminated surface soil, trees and so on were collected and isolated to decrease the radioactive exposure of the local populations. As a result, approximately 22 million $\mathrm{m}^{3}$ of decontamination waste was generated in the Fukushima prefecture, and $90 \%$ of the waste was removed soil [The ministry of environment, 2016]. Because Cs is strongly bound to clay in particle size fractions of soil (H. Tsukada et al. 2008), a technique for removing Cs from the collected soil using sieve classification and washing has been developed (K. Ito et al. 2012; M. Watanabe and A. Tagawa 2013, M.). After the treatment of the removed soil, concentrated highly radioactive soil and low radioactive soil will be generated. The concentrated highly radioactive soil will be disposed of at a final disposal site. However, the Ministry of the Environment, Japan, (MOE) defined policies for recycling the low radioactive soil as recycled soil for public projects. The corresponding recycling process management system and scheme for allocation of the responsibility of radiation protection must be clarified. Moreover, the MOE mandated that the use of the recycled soil in civil engineering structures whose forms cannot be changed artificially during the period when the management system is available must be limited. The use of the recycled soil for embankment and filling of roadways, coastal levees, and establishment of disaster-prevention forests near the coast, were examined to provide the relevant technical information for implementing these government policies (Sawaguchi, T et al. 2015; Takeda, S et al. 2014; Takai, S et al. 2018). In this study, land reclamation was assumed as a new application because significant usage of the recycled soil is expected. Based on the dose evaluation results, a concentration level for the use the recycled soil for land reclamation was derived. 


\section{Analytical method}

\subsection{Assumption of recycling of the recycled soil for landfill reclamation}

The target nuclides were ${ }^{134} \mathrm{Cs}$ and ${ }^{137} \mathrm{Cs}$, and the evaluation time was the end of March 2016 (5 y after the FDNPS accident). The ratio of ${ }^{134} \mathrm{Cs}$ to ${ }^{137} \mathrm{Cs}$ was found to be 0.209 based on the assumption that the ratio was 1 at the time of the accident. Furthermore, it was assumed that the recycled soil was used for landfill reclamation immediately after regeneration treatment of the removed soil five years after the accident.

In the disaster recovery projects, a significant amount of non-contaminated soil was required to restore the disaster area back to good condition. After the top soil was removed for use as a civil engineering material, a borrow pit remained at the excavation site. Many local governments required the environmental reclamation for the borrow pit. Therefore, the use of the recycled soil as landfill material for the borrow pit was targeted in this study. The size of the borrow pit was set to $500 \mathrm{~m} \times 500 \mathrm{~m}$, and its depth was $5 \mathrm{~m}$; these dimensions derived from the maximum volume recommended in the guidelines for landfill materials associated with the east Japan earthquake restoration and reconstruction [Miyagi prefecture 2012]. After landfilling, a layer of non-contaminated soil to plant grass or trees was laid as a cover. The depths of the cover soil layer for grass and trees were $0.3 \mathrm{~m}$ and $1 \mathrm{~m}$, respectively. The resulting landfilling depths were 4.7 and $4 \mathrm{~m}$, respectively.

Four cases were considered based on the types of plants and maintenance requirements as shown in Table 1, grass planting, and trees planting cases. The trees planting case was divided into 3 cases; coniferous, broad-leaf (thinning), and broad-leaf (non-thinning) tree planting cases. The timings of the trimming and thinning of the trees were set based on national forest field management plans for Pinus densiflora (coniferous trees) and Fagus crenata (broad-leaf trees) [Tohoku regional forest office]. After revegetation with grasses or trees, the green-covered area was used for sports or forest bathing.

Table 1 Settings of evaluated cases

\begin{tabular}{|c|c|c|c|c|}
\hline \multirow{2}{*}{ Plant } & Grass & \multicolumn{3}{|c|}{ Trees } \\
\cline { 3 - 5 } & & Coniferous trees & $\begin{array}{c}\text { Broad-leaf trees } \\
\text { (thinning) }\end{array}$ & $\begin{array}{c}\text { Broad-leaf trees } \\
\text { (non-thinning) }\end{array}$ \\
\hline Depth of landfill material /m & 4.7 & 4 & 4 & 4 \\
\hline Depth of cover soil /m & 0.3 & 1 & 1 & 1 \\
\hline Maintenance way & $\begin{array}{c}\text { Mowing } \\
\text { (3 times } \\
\text { per year) }\end{array}$ & $\begin{array}{c}\text { Periodic trimming } \\
\text { (beginning 7 y after } \\
\text { planting and } \\
\text { re-occurring every 5 y) } \\
\text { Trail maintenance }\end{array}$ & $\begin{array}{c}\text { Thinning } \\
\text { (49 y after planting) } \\
\text { Trail maintenance }\end{array}$ & Trail maintenance \\
\hline
\end{tabular}

\subsection{Scenario descriptions}

\subsubsection{Normal circumstances}

The scenarios and exposure pathways used to derive the clearance level of radioactive waste in Japan were adjusted for this estimation (shown in Table 2).

First is the transportation scenario. The recycled soil was loaded onto a truck at the regeneration treatment facility and subsequently transported to the landfill site. Considered exposed individual and exposure pathways were as follows:

-Worker for loading and unloading; external (No.1), inhalation (No.2), and ingestion (No.3)

-Worker for transportation; external (No.4)

-The public (adult and child) residing near the transportation route; external $($ No.5, 6)

Next is the construction scenario. A borrow pit was filled with recycled soil (after landfilling, the recycled soil is called landfill material), after which it was covered with non-contaminated soil. And then, revegetation with grass or trees was carried out. Considered exposed individual and exposure pathways were as follows:

-Worker for landfill; external (No.7), inhalation (No.8), and ingestion (No.9)

-The public (adult and child) residing near the landfill; external (No. 10, 12) and inhalation (No.11, 13)

-Worker for planting (grass or trees); external (No.14, 15) 
Table 2 List of scenarios and exposure pathways for land reclamation under normal circumstances

\begin{tabular}{|c|c|c|c|c|c|}
\hline No & & Scenario description & Source & $\begin{array}{l}\text { Exposed } \\
\text { individual }\end{array}$ & $\begin{array}{l}\text { Exposure } \\
\text { pathway }\end{array}$ \\
\hline 1 & \multirow{6}{*}{ Transportation } & \multirow{3}{*}{ Loading, Unloading } & \multirow{6}{*}{ Recycled soil } & \multirow{3}{*}{ Worker } & External \\
\hline 2 & & & & & Inhalation \\
\hline 3 & & & & & Ingestion \\
\hline 4 & & Transportation & & Worker & External \\
\hline 5 & & \multirow{2}{*}{ Residence near the transportation route } & & Adult & External \\
\hline 6 & & & & Child & External \\
\hline 7 & \multirow{9}{*}{ Construction } & \multirow{3}{*}{ Landfill } & \multirow{7}{*}{ Landfill material } & \multirow{3}{*}{ Worker } & External \\
\hline 8 & & & & & Inhalation \\
\hline 9 & & & & & Ingestion \\
\hline 10 & & \multirow{4}{*}{ Residence near the land reclamation site } & & \multirow{2}{*}{ Adult } & External \\
\hline 11 & & & & & Inhalation \\
\hline 12 & & & & \multirow{2}{*}{ Child } & External \\
\hline 13 & & & & & Inhalation \\
\hline 14 & & Grass planting & \multirow{2}{*}{ Landfill material } & Worker & External \\
\hline 15 & & Trees planting & & Worker & External \\
\hline 16 & \multirow{14}{*}{ In the service } & $\begin{array}{c}\text { Mowing } \\
\text { (Grass planting) }\end{array}$ & Landfill material & Worker & External \\
\hline 17 & & \multirow[t]{3}{*}{$\begin{array}{l}\text { Trimming, thinning, trail maintenance } \\
\text { (Trees planting) }\end{array}$} & $\begin{array}{c}\text { Landfill material, } \\
\text { Trees, Trimmed or } \\
\text { thinned trees, Organic } \\
\text { deposit } \\
\end{array}$ & Worker & External \\
\hline 18 & & & \multirow{2}{*}{$\begin{array}{l}\text { Dust from trees } \\
\text { material }\end{array}$} & \multirow{2}{*}{ Worker } & Inhalation \\
\hline 19 & & & & & Ingestion \\
\hline 20 & & \multirow{2}{*}{$\begin{array}{l}\text { Residence near the land reclamation site } \\
\text { (Grass planting) }\end{array}$} & \multirow[t]{2}{*}{ Landfill material } & Adult & External \\
\hline 21 & & & & Child & External \\
\hline 22 & & \multirow[b]{2}{*}{$\begin{array}{l}\text { Residence near the land reclamation site } \\
\text { (Trees planting) }\end{array}$} & \multirow{2}{*}{$\begin{array}{c}\text { Landfill material, } \\
\text { Trees, Trimmed or } \\
\text { thinned trees, Organic } \\
\text { deposit }\end{array}$} & Adult & External \\
\hline 23 & & & & Child & External \\
\hline 24 & & \multirow{2}{*}{$\begin{array}{l}\text { Use of the land reclamation site } \\
\text { (Grass planting) }\end{array}$} & \multirow{2}{*}{ Landfill material } & Adult & External \\
\hline 25 & & & & Child & External \\
\hline 26 & & \multirow{4}{*}{$\begin{array}{l}\text { Use of the land reclamation site } \\
\text { (Trees planting) }\end{array}$} & \multirow{2}{*}{$\begin{array}{l}\text { Landfill material, } \\
\text { Trees, Trimmed trees, } \\
\text { Organic deposit }\end{array}$} & Adult & External \\
\hline 27 & & & & Child & External \\
\hline 28 & & & \multirow{2}{*}{$\begin{array}{c}\text { Dust from trees } \\
\text { material }\end{array}$} & Adult & Inhalation \\
\hline 29 & & & & Child & Inhalation \\
\hline 30 & & Incoction of wutor & W/ll wotor & Adult, & Ingestion \\
\hline 31 & & ingestion or water & wenl water & Child & Ingestion \\
\hline 32 & & Agriculture & $\begin{array}{l}\text { Soil irradiated well } \\
\text { water }\end{array}$ & Worker & External \\
\hline 33 & & Ingestion of crons & Crops cultivated with & Adult & Ingestion \\
\hline 34 & & ingestion of crops & well water & Child & Ingestion \\
\hline 35 & $\begin{array}{l}\text { migration } \\
\text { mind }\end{array}$ & & Livestock grown with & Adult & Ingestion \\
\hline 36 & & Ingestion of livestock & $\begin{array}{l}\text { feeds cultivated with } \\
\text { well water }\end{array}$ & Child & Ingestion \\
\hline 37 & & Inoestion of livestock & Livestock grown with & Adult & Ingestion \\
\hline 38 & & ingestion or IIVestock & well water & Child & Ingestion \\
\hline 39 & & & Fishery products & Adult & Ingestion \\
\hline 40 & & on of tishery products & farmed with well water & Child & ingestion \\
\hline
\end{tabular}


After construction, the green-covered area was serviced for the public, in the service scenario.

In the case of grass planting, only the landfill material was considered as the radiation source. Considered exposed individual and exposure pathways were as follows:

-Worker for mowing; external (No.16)

-The public (adult and child) residing near the land reclamation site; external (No.20, 21)

- The public (adult and child) using the revegetated area; external (No.24, 25)

In the case of tree planting, the roots reached the landfill material $2 \mathrm{y}$ after planting based on the assumption that the roots grew $4 \mathrm{~cm}$ a month. For the safety side evaluation, radiocesium was assumed to be distributed in the entire tree body 2 y after planting. It was assumed that trimmed or thinned trees were remained on the forest floor uniformly. Furthermore, it was assumed that litter fall formed organic deposits and radioactivity was accumulated in the organic deposits by new litter fall.

In the case of coniferous tree planting, periodic trimming (beginning $7 \mathrm{y}$ after planting and re-occurring every $5 \mathrm{y}$ ) was considered. Therefore, radiation source are changed by time; immediately after planting $(0 \mathrm{y}$, the radiation source is only the landfill material), 2 years after planting ( $2 \mathrm{y}$, the radiation sources are the landfill material and trees), before trimming at 7 years after planting (the radiation sources are the landfill material, trees, and organic deposit), and before and after trimming at 7, 12, 17, 22, 27, 32, 37, 42, and 47 years (the radiation sources are the landfill material, trees, organic deposits, and trimmed trees). Because of the change of radiation source mentioned above, growth of trees absorbed radiocesium and radiation decay, external exposure dose was changed by time. Therefore, the external exposure dose was evaluated by using the maximum value. Moreover, inhalation exposure due to dust generated from tree material were considered when a person entered to the land reclamation site. In addition, ingestion exposure was considered for worker. Considered exposed individual and exposure pathways were as follows:

-Worker for trimming and trail maintenance; external (No.17), inhalation (No.18), ingestion (No.19)

-The public (adult and child) residing near the revegetated area; external (No.22, 23)

-The public (adult and child) using the revegetated area; external (No.26, 27), inhalation (No.28, 29)

In the case of broad-leaf tree planting, thinning was carried out only 1 time at $49 \mathrm{y}$ after planting (thinning case) or not carried out (non-thinning case). Radiation source was mainly changed by the growth of trees and accumulation of organic deposit. Therefore, external exposure doses were studied at the timing as follows; immediately after planting $(0$ $\mathrm{y}$, the radiation source is only the landfill material), 2 years after planting ( $2 \mathrm{y}$, the radiation sources are the landfill material and trees), 9, 19, 29, 39, 49, 59, 69, and 79 years after planting for the thinning (radiation source are landfill material, trees, and organic deposit for 9, 19, 29, 39 y, and radiation source are landfill material, trees, organic deposit, and thinned trees for 49, 59,69, $79 \mathrm{y}$ ) and non-thinning cases (radiation source are landfill material, trees , and organic deposit). The maximum value was obtained to evaluate the external exposure. Considered exposed individual and exposure pathways were the same as coniferous tree planting case.

A groundwater migration scenario was also considered. Radiocesium dissolved due to precipitation and migrated into groundwater. The use of groundwater as well water was therefore considered in this study. Considered exposed individual and exposure pathways were as follows.

-The public (adult and child) drinking well water; ingestion (No.30, 31)

-Worker at the field irradiated with well water; external (No.32)

-The public (adult and child) eating crops cultivated with well water, livestock grown with feeds irrigated with well water, livestock supplied with well water, and fishery products farmed with well water; ingestion (No.33, 34, 35, 36, $37,38,39,40)$.

\subsubsection{Natural disaster circumstances}

Tsunamis, fires, and intense heavy rain were considered as possible disasters that can enhance the exposure doses by changing the conditions of the land reclamation site. The scenario and exposure pathway under natural disaster circumstances are summarized in Table 3. Because it is challenging to estimate the damages, severe cases were assumed.

In the case of tsunamis, the cover soil was stripped by the tsunami to expose the landfill material. External, inhalation, and ingestion exposure were considered for the rehabilitation workers (No.d1, d2, d3), and external exposure was considered for members of the public (adult and child) residing near the landfill (No.d4, d5).

In the case of fires, $80 \%$ of the Cs transferred trees were burned by fire (corresponding to $200000 \mathrm{~m}^{2}$ ), resulting in 
a plume containing radiocesium. External and inhalation exposure were considered for firefighters and the public due to the plume (No.d6, d7, d10, d11). The plume was deposited on the ground surface; therefore external exposure of firefighters and the public residing near the land reclamation site from surface deposition were considered (No.d8, d9, $\mathrm{d} 12, \mathrm{~d} 13)$.

It was assumed that the amount of penetrated water was increased from $0.4 \mathrm{~m} / \mathrm{y}$ (normal circumstances) to $1 \mathrm{~m} / \mathrm{y}$ because of the intense heavy rain, which is the maximum penetrated amount of water for the evaluation of the clearance level of radioactive waste [Japanese groundwater editorial board], to increase the migration of Cs into groundwater. The groundwater migration scenario was evaluated in the same manner, using the increased amount of penetrated water (No.d14-d24).

Table 3 List of scenarios and exposure pathways for land reclamation under natural disaster circumstances

\begin{tabular}{|c|c|c|c|c|c|}
\hline No & \multicolumn{2}{|c|}{ Scenario description } & Source & Exposed & Exposure \\
\hline $\mathrm{d} 1$ & \multirow[t]{5}{*}{ Tsunami } & \multirow[t]{3}{*}{ Rehabilitation work } & \multirow{5}{*}{$\begin{array}{l}\text { Exposed landfill } \\
\text { material }\end{array}$} & \multirow[t]{3}{*}{ Worker } & External \\
\hline $\mathrm{d} 2$ & & & & & Inhalation \\
\hline $\mathrm{d} 3$ & & & & & Ingestion \\
\hline $\mathrm{d} 4$ & & \multirow{2}{*}{$\begin{array}{l}\text { Residence near the } \\
\text { landfill reclamation } \\
\text { site }\end{array}$} & & Adult & External \\
\hline $\mathrm{d} 5$ & & & & Child & External \\
\hline d6 & \multirow[t]{8}{*}{ Fire } & \multirow[t]{4}{*}{ Fire fighting } & \multirow[t]{2}{*}{ plume } & \multirow[t]{4}{*}{ Firefighter } & External \\
\hline $\mathrm{d} 7$ & & & & & Inhalation \\
\hline $\mathrm{d} 8$ & & & \multirow[t]{2}{*}{ Surface deposition } & & External \\
\hline d9 & & & & & Inhalation \\
\hline $\mathrm{d} 10$ & & \multirow{4}{*}{$\begin{array}{l}\text { Residence near the } \\
\text { landfill reclamation } \\
\text { site }\end{array}$} & \multirow[t]{2}{*}{ plume } & \multirow[t]{4}{*}{ Public } & External \\
\hline $\mathrm{d} 11$ & & & & & Inhalation \\
\hline $\mathrm{d} 12$ & & & Surface deposition & & External \\
\hline $\mathrm{d} 13$ & & & & & Inhalation \\
\hline $\mathrm{d} 14$ & \multirow{11}{*}{$\begin{array}{l}\text { Concentrated } \\
\text { heavy rain }\end{array}$} & \multirow[t]{2}{*}{ Ingestion of water } & \multirow[t]{2}{*}{ Well water } & Adult, & Ingestion \\
\hline $\mathrm{d} 15$ & & & & Child & ingestion \\
\hline d16 & & Agriculture & $\begin{array}{l}\text { Soil irradiated well } \\
\text { water }\end{array}$ & Worker & External \\
\hline $\mathrm{d} 17$ & & \multirow[t]{2}{*}{ Ingestion of crops } & \multirow{2}{*}{$\begin{array}{l}\text { Crops cultivated } \\
\text { with well water }\end{array}$} & Adult & Ingestion \\
\hline $\mathrm{d} 18$ & & & & Child & Ingestion \\
\hline $\mathrm{d} 19$ & & \multirow[t]{2}{*}{ Ingestion of livestock } & \multirow{2}{*}{$\begin{array}{l}\text { Livestock grown } \\
\text { with feeds } \\
\text { cultivated with well } \\
\text { water }\end{array}$} & Adult & Ingestion \\
\hline $\mathrm{d} 20$ & & & & Child & Ingestion \\
\hline $\mathrm{d} 21$ & & \multirow[t]{2}{*}{ Ingestion of livestock } & \multirow{2}{*}{$\begin{array}{l}\text { Livestock grown } \\
\text { with well water }\end{array}$} & Adult & Ingestion \\
\hline $\mathrm{d} 22$ & & & & Child & Ingestion \\
\hline $\mathrm{d} 23$ & & \multirow{2}{*}{$\begin{array}{l}\text { Ingestion of fishery } \\
\text { products }\end{array}$} & \multirow{2}{*}{$\begin{array}{l}\text { Fishery products } \\
\text { farmed with well } \\
\text { water }\end{array}$} & Adult & Ingestion \\
\hline $\mathrm{d} 24$ & & & & Child & ingestion \\
\hline
\end{tabular}

\subsection{Model, parameters, and codes}

\subsubsection{Outline of used model, parameters, and codes}

The dose estimation models and parameters used to derive the clearance level of radioactive waste in Japan which are equivalent to the models and parameters in IAEA Safety Guide No. RS-G-1.7 were applied to this estimation and calculated using the PASCLR2 code (Takeda, S et al., 2006). However, based on the survey results of the operation process of land reclamation and land usage, a realistic model and parameters were set. Where it is challenging to set realistic parameters like the size of the land reclamation site, conservative values for the parameters were used as the maximum volume. For all the dose estimations, the exposure period was set to 1 year, and the radioactive decay during the exposure period was factored into the model. 
A heavy machine was used for loading and unloading of the recycled soil, and the shielding factor was set to 0.4 (No.1). The shielding factor during transportation was calculated as 0.9 (No.4). The external exposure factors of ${ }^{134} \mathrm{Cs}$ and ${ }^{137} \mathrm{Cs}$ were $5.9 \times 10^{-2}$ and $2.1 \times 10^{-2} \mu \mathrm{Sv} / \mathrm{h}$ per Bq/g, respectively, calculated by QAD-CGGP2R code [Sakamoto, Y., et al., 1990] for the loaded recycled soil with dimensions of $0.6 \mathrm{~m}$ height, $2 \mathrm{~m}$ width, and $5 \mathrm{~m}$ length. The evaluation point was $1 \mathrm{~m}$ from the middle point of $0.6 \mathrm{~m}$ and the $5 \mathrm{~m}$ side (No.1, 4). The density of the recycled soil was set to 1.7 $\mathrm{g} / \mathrm{cm}^{3}$ based on the average density of natural ground soil (No.1-6), that of the landfill material was set to $2.0 \mathrm{~g} / \mathrm{cm}^{3}$ based on the maximum value of consolidated soil (No.7-40); that of cover soil was set to $1.5 \mathrm{~g} / \mathrm{cm}^{3}$ based on the value of the road embankment material (No.14-29). The working time was set to $1000 \mathrm{~h} / \mathrm{y}$ (No.1-4, 7-9, 14, 15, 17-19) by assuming that workers work near the recycled soil or landfill material for half of their working time. The working durations were $8 \mathrm{~h} / \mathrm{d}$ and $250 \mathrm{~d} / \mathrm{y}$. In the case of mowing, $250 \mathrm{~h} / \mathrm{y}$ was set derived from 3 times/year, 10 days/time, and $8 \mathrm{~h} /$ day. The exposure time for residents near the transportation route was set to $450 \mathrm{~h} / \mathrm{y}$ assuming 2250 trucks per month stop at a nearby red signal for $1 \mathrm{~min}$ (No.5, 6). The exposure time for residents near the landfill reclamation site was set to $8760 \mathrm{~h} / \mathrm{y}$, and the shielding factor was set to 0.2 [IAEA-TECDOC-401] (No.20-23). The growth of the trees over time with or without tree trimming was postulated based on the national forest field management plans for Pinus densiflora (coniferous trees) and Fagus crenata (broad-leaf trees) [Tohoku regional forest office].Transfer factor of 0.0055 (Tagami. K. and Uchida, K., 2010) was used for the absorption of radiocesium by trees. The depth of the organic deposits was set to $3 \mathrm{~cm}$ because $3 \mathrm{~cm}$ depth of the mulch layer was removed for decontamination at Minami-soma city [Japan Atomic Energy Agency, 2012, K. Henmi et al, 2017]. Although the volume of the organic deposits was constant, an increase due to new litter fall and a decrease due to digestion occurred. Although the amount of litter fall depends on the sites, the measured values of $580.09 \mathrm{~g} /\left(\mathrm{m}^{2} \cdot \mathrm{y}\right)$ for the Pinus densiflora forest (K. Iharakawa and H. Nakagawa, 2002) and $437.2 \mathrm{~g} /\left(\mathrm{m}^{2} \cdot \mathrm{y}\right)$ for broad-leaf trees (T. Kawabara, 1985), were used. Dust concentration during work was $5 \times 10^{-4} \mathrm{~g} / \mathrm{m}^{3}$ [IAEA-TECDOC-401] The enrichment factors into fine particles were 4 and 2 for inhalation and ingestion exposures, respectively [IAEA Safety Reports Series No.44] (No. 2, 3, 8, 9, 11, 13, 18, 19, 28, 29). Respiratory volumes for the workers and the public (adult and child) were $1.2,0.96$, and $0.22 \mathrm{~m}^{3} / \mathrm{h}$, respectively [ICRP Publ.23] and ingestion rate was 0.01 g/h [IAEA S.S. No.111-P1.1] (No. 2, 3, 8, 9, 11, 13, 18, 19, 28, 29).

The porosity of the landfill material was calculated as 0.25 from the real density and bulk density of the landfill material (No.30-40). The distribution ratio of Cs in the landfill material, aquifer, and agricultural soil was set to 270 $\mathrm{mL} / \mathrm{g}$ [IAEA TRS No.364] (No.30-40). The amount of penetrated water was set to $0.4 \mathrm{~m} / \mathrm{y}$ (Takeda, S et al., 2006) (No.30-40). The thickness of the aquifer was set to $3 \mathrm{~m}$ [IAEA-TECDOC 401] (No.30-40). The flow rate of the groundwater was set to $1 \mathrm{~m} / \mathrm{d}$ (S. Yamamoto, New edition survey method of groundwater, 1983). The porosity and density of the aquifer were set to 0.3 (Japan society of civil engineers, Pack of hydraulic formula 1971) and $2.6 \mathrm{~g} / \mathrm{cm}^{3}$ (Japan Geotechnical Society, Handbook of soil engineering, 1982), respectively (No.30-40). The dispersion length and factor for the direction of groundwater flow were set to $0 \mathrm{~m}$ and $0 \mathrm{~m}^{2} / \mathrm{y}$, respectively, for conservative estimation. The distance from the land reclamation site to a well was set to $0 \mathrm{~m}$ for conservative estimation. The mixture rate of groundwater was set to 0.33 (Editorial committee for handbook of groundwater, Handbook of groundwater, 1979). The consumption of water for an adult and a child were $0.61 \mathrm{~m}^{3} / \mathrm{y}$ (ICRP Pub.23) (No.30) and $0.1 \mathrm{~m}^{3} / \mathrm{y}$ (IAEA Safety Reports Series No.44) (No.31), respectively. The working time for agriculture was set to $500 \mathrm{~h} / \mathrm{y}$ (Ministry of Internal Affairs and Communications, Statistic of Japan) (No.32). The annual dose effective conversion factor for agriculture was calculated using QAD-CGGP2R, which was 0.47 and 0.17 for ${ }^{134} \mathrm{Cs}$ and ${ }^{137} \mathrm{Cs}$, respectively (No.32). The transfer factors of Cs into crops, livestock, and fishery products were set based on reference (IAEA TRS No. 364) (No.33-40). The amount of consumption of the crops, livestock, and fishery products was set based on a static survey (Ministry of Health and Welfare, 1996-1997) (No.33-40).

The same average density of the landfill material, dust concentration, enrichment factor into fine particles for inhalation and ingestion were set for the tsunami disaster case (No.d1-d5). The shielding factor during the rehabilitation work was set to 1 for conservative evaluation (No.d1). The working time for rehabilitation work was set to $500 \mathrm{~h} / \mathrm{y}$ derived from $8 \mathrm{~h} / \mathrm{d}$ and $60 \mathrm{~d} / \mathrm{y}$ (No.d1-3). The shielding factor and exposure time for residents near the land reclamation site was set 0.2 and $2160 \mathrm{~h} / \mathrm{y}$ derived from the rehabilitation period of 3 months/year (No.d4, d5).

Submersion (No.d6-d9) and Gaussian plume (No.d10-d13) models were used to estimate the air conditions for the firefighter and public member residing near the land reclamation site, respectively, for the fire disaster case. The conditions in which the exposure dose was the highest were selected to estimate the exposure doses.

The same parameters for groundwater migration, except the amount of penetrated water, $1 \mathrm{~m} / \mathrm{y}$, were used for the 
intense heavy rain scenario.

\subsubsection{Calculation of external effective dose conversion factors}

By considering the realistic elemental ratios and densities of soil, and the accumulated organic phase, the external effective dose conversion factors were calculated using MCNP5 [X-5 Monte Carlo team, 1987] or QAD-CGGP2R [Sakamoto, Y. 1990]. In order to ensure the conservativeness of estimation of external exposure dose, the evaluation point for the all workers and public users in the revegetated areas was set at the center of the land reclamation site at a height of $1 \mathrm{~m}$ above the ground surface. The evaluation point for members of the public residing near the revegetated areas was set $1 \mathrm{~m}$ from the center of the border of the land reclamation site and $1 \mathrm{~m}$ above the ground. Based on the realistic temporal changes from the growth of trees, number of trees, timber volume, number of trimmed or thinned trees [Tohoku regional forest office, 2002], volume of the forest and quantity of Cs transferred from the landfill material to the trees were calculated. The radiation source system and evaluation points are shown in Fig.1. As mentioned above, radioactive Cs was absorbed by the trees, they became radioactive. However, it is challenging to set real tree shapes as sources. Therefore, the area consisting of the trees and air was simulated as an area saturated with air, which showed the highest external effective conversion factors because of the absence of a radiation shield. However, the central part of $20 \mathrm{~m}$ by $20 \mathrm{~m}$ with a tree height $\mathrm{m}$ at the land reclamation site for each evaluation time was calculated by setting the line source simulated trees when the evaluation point was inside the land reclamation site. Trimmed or thinned trees were assumed to be placed uniformly on the forest floor. It was assumed that litter fall produced $3 \mathrm{~cm}$ organic deposits above the ground, and radiocesium from litter fall accumulated in this layer.

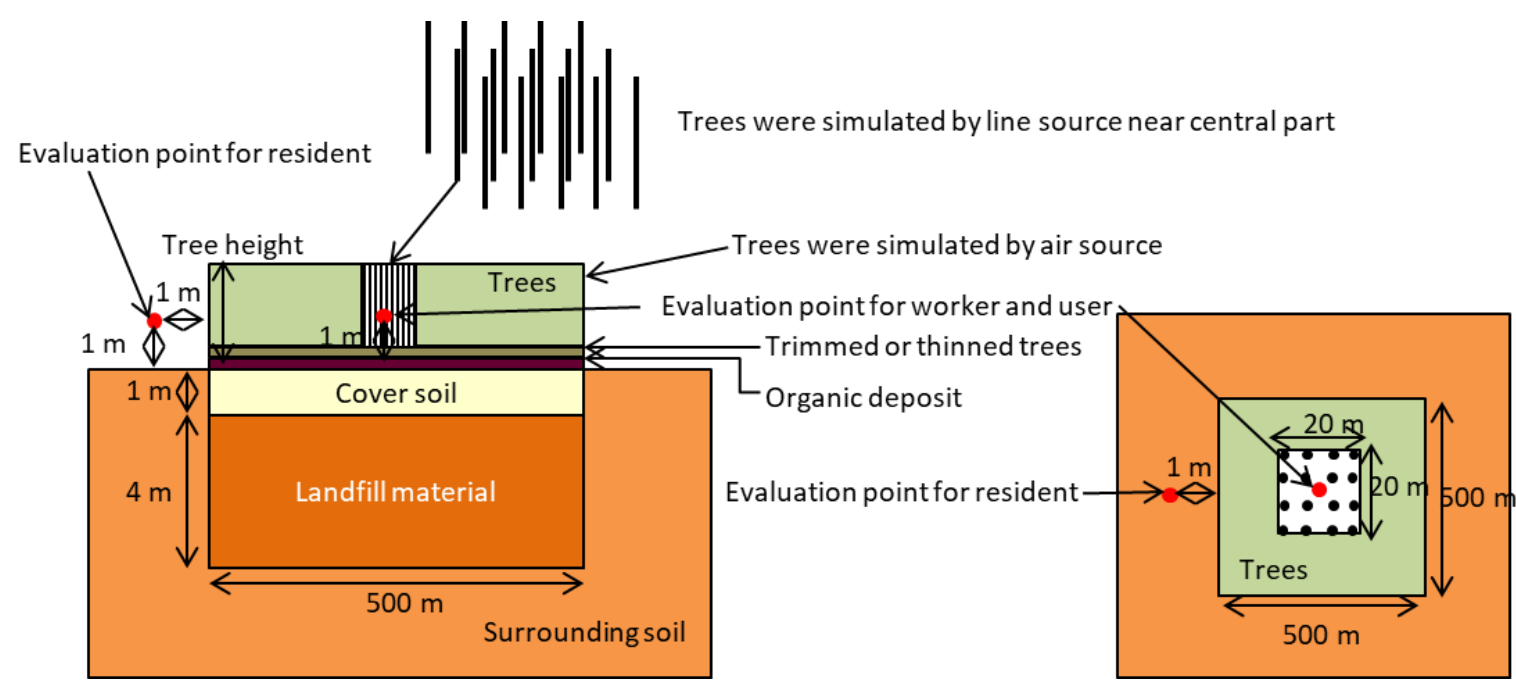

Fig.1 Radiation source systems and evaluation points for calculation of effective dose conversion factors

\section{Results and discussions}

\subsection{Dose estimation transportation and in service scenario}

As shown in Table 2, the landfill material, trees, trimmed or thinned trees, and organic deposits were set as sources, and external effective dose conversion factors were calculated separately. The external effective dose conversion factors from the landfill material are summarized in Table 4. The calculated external effective dose conversion factors from the trees, trimmed or thinned trees, and organic deposits are summarized in Tables 5-8. The effective dose from external exposure was calculated by equation (1) [S. Takai et al., 2018], using the calculated effective dose conversion factors. Furthermore, the effective doses from inhalation and ingestion exposure were also similarly calculated [S. Takai et al., 2018].

$D_{\text {ext }}(t)=C_{M}(0) \cdot \times 10^{-6} \cdot F_{S} \cdot t_{e} \cdot D F_{\text {ext }} \cdot \frac{1-\exp (-\lambda t)}{\lambda t}$

where, $C_{M}(0)$ is the radiocesium concentration of the landfill material, $F_{S}$ is the shielding factor, $t_{\mathrm{e}}$ is the annual exposure duration $(\mathrm{h} / \mathrm{y}), D F_{\text {ext }}$ is the external effective dose conversion factor, $\lambda$ is the decay constant $(1 / \mathrm{y})$, and $\mathrm{t}$ is the evaluation time $(\mathrm{y})$.

Figures $2 \mathrm{a}$ and $\mathrm{b}$ show the time dependence of the annual effective dose due to the landfill material with radioactivity of $1 \mathrm{~Bq} / \mathrm{g}$ for coniferous trees (a) and broad-leaf trees (b). Although the radioactivity of Cs decreased with 
time, the amount of absorbed Cs by the trees increased as the trees grew. Consequently, the maximum annual effective doses due to the landfill material with radioactivity of $1 \mathrm{~Bq} / \mathrm{g}$ were $37 \mathrm{y}$ after planting and before trimming of the coniferous trees and $49 \mathrm{y}$ after planting of broad-leaf trees, respectively. Therefore, the dose evaluation was performed using the value of $37 \mathrm{y}$ before trimming for coniferous trees, and $49 \mathrm{y}$ for broad-leaf trees. The highest annual effective dose was obtained for workers in all cases. The highest to the lowest effective dose categories were the workers, residents (child), residents (adult), users (child), and users (adult). The thinning case showed a slightly higher annual effective dose due to landfill material with radioactivity of $1 \mathrm{~Bq} / \mathrm{g}$ compare to the non-thinning case because the thinned trees remained on the forest floor in this setting and the timber volume per a tree increased because of thinning.

Table 4 External effective dose conversion factor $((\mu \mathrm{Sy} / \mathrm{y})$ per $(\mathrm{Bq} / \mathrm{g}))$ of the landfill material calculated by MCNP5 code

\begin{tabular}{|c|c|c|c|c|c|}
\hline & & \multicolumn{2}{|c|}{ Grasses planting case } & \multicolumn{2}{|c|}{ Trees planting case } \\
\hline & & ${ }^{134} \mathrm{Cs}$ & ${ }^{137} \mathrm{Cs}$ & ${ }^{134} \mathrm{Cs}$ & ${ }^{137} \mathrm{Cs}$ \\
\hline \multirow[t]{3}{*}{ construction } & $\begin{array}{c}\text { Worker } \\
\text { (landfilling) }\end{array}$ & $4.5 \times 10^{-1}$ & $1.7 \times 10^{-1}$ & $4.4 \times 10^{-1}$ & $1.7 \times 10^{-1}$ \\
\hline & Worker (planting) & $1.6 \times 10^{-2}$ & $5.5 \times 10^{-3}$ & $1.4 \times 10^{-5}$ & $3.3 \times 10^{-6}$ \\
\hline & $\begin{array}{c}\text { Residence near the } \\
\text { land reclamation } \\
\text { site }\end{array}$ & $1.3 \times 10^{-1}$ & $4.9 \times 10^{-2}$ & $1.2 \times 10^{-1}$ & $4.9 \times 10^{-2}$ \\
\hline \multirow[t]{2}{*}{ In the service } & Worker, user & $1.6 \times 10^{-2}$ & $5.5 \times 10^{-3}$ & $1.4 \times 10^{-5}$ & $3.1 \times 10^{-6}$ \\
\hline & $\begin{array}{c}\text { Residence near the } \\
\text { land reclamation } \\
\text { site }\end{array}$ & $3.8 \times 10^{-3}$ & $1.4 \times 10^{-3}$ & $3.1 \times 10^{-6}$ & $7.3 \times 10^{-7}$ \\
\hline
\end{tabular}

Table 5 External effective dose conversion factor $((\mu \mathrm{Sy} / \mathrm{y})$ per $(\mathrm{Bq} / \mathrm{g}))$ for worker and user calculated by MCNP5 code (coniferous trees)

\begin{tabular}{|c|c|c|c|c|c|c|}
\hline \multirow{2}{*}{$\begin{array}{c}\text { Year after } \\
\text { planting, } \\
\text { before or after } \\
\text { trimming }\end{array}$} & \multicolumn{3}{|c|}{${ }^{134} \mathrm{Cs}$} & \multicolumn{3}{|c|}{${ }^{137} \mathrm{Cs}$} \\
\hline & Trees & Trimmed trees & $\begin{array}{l}\text { Organic } \\
\text { deposit }\end{array}$ & Trees & Trimmed trees & $\begin{array}{l}\text { Organic } \\
\text { deposit }\end{array}$ \\
\hline 2 & $8.0 \times 10^{-3}$ & - & - & $3.1 \times 10^{-3}$ & - & - \\
\hline 7 , before & $2.5 \times 10^{-2}$ & - & \multirow{2}{*}{$1.6 \times 10^{-2}$} & $9.7 \times 10^{-3}$ & - & \multirow{2}{*}{$6.0 \times 10^{-3}$} \\
\hline 7, after & $1.0 \times 10^{-2}$ & $1.9 \times 10^{-2}$ & & $3.9 \times 10^{-3}$ & $7.2 \times 10^{-3}$ & \\
\hline 12 , before & $2.6 \times 10^{-2}$ & $1.9 \times 10^{-2}$ & \multirow{2}{*}{$3.1 \times 10^{-2}$} & $1.0 \times 10^{-2}$ & $7.2 \times 10^{-3}$ & \multirow{2}{*}{$1.2 \times 10^{-2}$} \\
\hline 12, after & $2.0 \times 10^{-2}$ & $2.4 \times 10^{-2}$ & & $7.8 \times 10^{-3}$ & $9.3 \times 10^{-3}$ & \\
\hline 17 , before & $4.7 \times 10^{-2}$ & $2.4 \times 10^{-2}$ & \multirow{2}{*}{$4.7 \times 10^{-2}$} & $1.8 \times 10^{-2}$ & $9.3 \times 10^{-3}$ & \multirow{2}{*}{$1.8 \times 10^{-2}$} \\
\hline 17, after & $3.1 \times 10^{-2}$ & $4.3 \times 10^{-2}$ & & $1.2 \times 10^{-2}$ & $1.7 \times 10^{-2}$ & \\
\hline 22, before & $6.0 \times 10^{-2}$ & $4.3 \times 10^{-2}$ & \multirow{2}{*}{$6.2 \times 10^{-2}$} & $2.3 \times 10^{-2}$ & $1.7 \times 10^{-2}$ & \multirow{2}{*}{$2.4 \times 10^{-2}$} \\
\hline 22, after & $4.2 \times 10^{-2}$ & $6.4 \times 10^{-2}$ & & $1.6 \times 10^{-2}$ & $2.5 \times 10^{-2}$ & \\
\hline 27, before & $7.2 \times 10^{-2}$ & $6.4 \times 10^{-2}$ & \multirow{2}{*}{$7.8 \times 10^{-2}$} & $2.8 \times 10^{-2}$ & $2.5 \times 10^{-2}$ & \multirow{2}{*}{$3.0 \times 10^{-2}$} \\
\hline 27, after & $5.6 \times 10^{-2}$ & $8.3 \times 10^{-2}$ & & $2.1 \times 10^{-2}$ & $3.2 \times 10^{-2}$ & \\
\hline 32 , before & $8.2 \times 10^{-2}$ & $8.3 \times 10^{-2}$ & \multirow{2}{*}{$9.4 \times 10^{-2}$} & $3.1 \times 10^{-2}$ & $3.2 \times 10^{-2}$ & \multirow{2}{*}{$3.6 \times 10^{-2}$} \\
\hline 32 , after & $6.2 \times 10^{-2}$ & $9.8 \times 10^{-2}$ & & $2.4 \times 10^{-2}$ & $3.8 \times 10^{-2}$ & \\
\hline 37, before & $8.6 \times 10^{-2}$ & $9.8 \times 10^{-2}$ & \multirow{2}{*}{$1.1 \times 10^{-1}$} & $3.3 \times 10^{-2}$ & $3.8 \times 10^{-2}$ & \multirow{2}{*}{$4.2 \times 10^{-2}$} \\
\hline 37 , after & $7.0 \times 10^{-2}$ & $1.1 \times 10^{-1}$ & & $2.7 \times 10^{-2}$ & $4.3 \times 10^{-2}$ & \\
\hline 42 , before & $9.0 \times 10^{-2}$ & $1.1 \times 10^{-1}$ & \multirow{2}{*}{$1.2 \times 10^{-1}$} & $3.4 \times 10^{-2}$ & $4.3 \times 10^{-2}$ & \multirow{2}{*}{$4.8 \times 10^{-2}$} \\
\hline 42 , after & $7.5 \times 10^{-2}$ & $1.2 \times 10^{-1}$ & & $2.9 \times 10^{-2}$ & $4.7 \times 10^{-2}$ & \\
\hline 47, after & $9.4 \times 10^{-2}$ & $1.2 \times 10^{-1}$ & \multirow{2}{*}{$1.4 \times 10^{-1}$} & $3.6 \times 10^{-2}$ & $4.7 \times 10^{-2}$ & \multirow{2}{*}{$5.4 \times 10^{-2}$} \\
\hline 47, before & $9.1 \times 10^{-2}$ & $1.3 \times 10^{-1}$ & & $3.5 \times 10^{-2}$ & $5.2 \times 10^{-2}$ & \\
\hline
\end{tabular}


Table 6 External effective dose conversion factor $((\mu \mathrm{Sy} / \mathrm{y})$ per $(\mathrm{Bq} / \mathrm{g}))$ for members of public residing near the land reclamation site calculated by MCNP5 code (coniferous trees)

\begin{tabular}{|c|c|c|c|c|c|c|}
\hline \multirow{2}{*}{$\begin{array}{l}\text { Year after } \\
\text { planting, } \\
\text { before or after } \\
\text { trimming }\end{array}$} & \multicolumn{3}{|c|}{${ }^{134} \mathrm{Cs}$} & \multicolumn{3}{|c|}{${ }^{137} \mathrm{Cs}$} \\
\hline & Trees & Trimmed trees & $\begin{array}{l}\text { Organic } \\
\text { deposit }\end{array}$ & Trees & Trimmed trees & $\begin{array}{l}\text { Organic } \\
\text { deposit }\end{array}$ \\
\hline 2 & $3.0 \times 10^{-3}$ & - & - & $1.1 \times 10^{-3}$ & - & - \\
\hline 7 , before & $1.0 \times 10^{-2}$ & - & \multirow{2}{*}{$6.0 \times 10^{-3}$} & $3.9 \times 10^{-3}$ & - & \multirow{2}{*}{$2.3 \times 10^{-3}$} \\
\hline 7, after & $4.0 \times 10^{-3}$ & $7.4 \times 10^{-3}$ & & $1.5 \times 10^{-3}$ & $2.8 \times 10^{-3}$ & \\
\hline 12 , before & $1.1 \times 10^{-2}$ & $7.4 \times 10^{-3}$ & \multirow{2}{*}{$1.2 \times 10^{-2}$} & $4.2 \times 10^{-3}$ & $2.8 \times 10^{-3}$ & \multirow{2}{*}{$4.6 \times 10^{-3}$} \\
\hline 12 , after & $9.0 \times 10^{-3}$ & $9.4 \times 10^{-3}$ & & $3.5 \times 10^{-3}$ & $3.6 \times 10^{-3}$ & \\
\hline 17 , before & $2.1 \times 10^{-2}$ & $9.4 \times 10^{-3}$ & \multirow{2}{*}{$1.8 \times 10^{-2}$} & $8.1 \times 10^{-3}$ & $3.6 \times 10^{-3}$ & \multirow{2}{*}{$6.9 \times 10^{-3}$} \\
\hline 17, after & $1.4 \times 10^{-2}$ & $1.6 \times 10^{-2}$ & & $5.4 \times 10^{-3}$ & $6.3 \times 10^{-3}$ & \\
\hline 22 , before & $2.8 \times 10^{-2}$ & $1.6 \times 10^{-2}$ & \multirow{2}{*}{$2.4 \times 10^{-2}$} & $1.1 \times 10^{-2}$ & $6.3 \times 10^{-3}$ & \multirow{2}{*}{$9.2 \times 10^{-3}$} \\
\hline 22, after & $1.9 \times 10^{-2}$ & $2.4 \times 10^{-2}$ & & $7.4 \times 10^{-3}$ & $9.1 \times 10^{-3}$ & \\
\hline 27 , before & $3.3 \times 10^{-2}$ & $2.4 \times 10^{-2}$ & \multirow{2}{*}{$3.0 \times 10^{-2}$} & $1.3 \times 10^{-2}$ & $9.1 \times 10^{-3}$ & \multirow{2}{*}{$1.2 \times 10^{-2}$} \\
\hline 27 , after & $2.4 \times 10^{-2}$ & $3.0 \times 10^{-2}$ & & $9.4 \times 10^{-3}$ & $1.2 \times 10^{-2}$ & \\
\hline 32 , before & $3.6 \times 10^{-2}$ & $3.0 \times 10^{-2}$ & \multirow{2}{*}{$3.6 \times 10^{-2}$} & $1.4 \times 10^{-2}$ & $1.2 \times 10^{-2}$ & \multirow{2}{*}{$1.4 \times 10^{-2}$} \\
\hline 32, after & $2.9 \times 10^{-2}$ & $3.5 \times 10^{-2}$ & & $1.1 \times 10^{-2}$ & $1.4 \times 10^{-2}$ & \\
\hline 37 , before & $4.0 \times 10^{-2}$ & $3.5 \times 10^{-2}$ & \multirow{2}{*}{$4.2 \times 10^{-2}$} & $1.5 \times 10^{-2}$ & $1.4 \times 10^{-2}$ & \multirow{2}{*}{$1.6 \times 10^{-2}$} \\
\hline 37 , after & $3.4 \times 10^{-2}$ & $3.9 \times 10^{-2}$ & & $1.3 \times 10^{-2}$ & $1.5 \times 10^{-2}$ & \\
\hline 42 , before & $4.3 \times 10^{-2}$ & $3.9 \times 10^{-2}$ & \multirow{2}{*}{$4.8 \times 10^{-2}$} & $1.7 \times 10^{-2}$ & $1.5 \times 10^{-2}$ & \multirow{2}{*}{$1.8 \times 10^{-2}$} \\
\hline 42 , after & $3.7 \times 10^{-2}$ & $4.3 \times 10^{-2}$ & & $1.4 \times 10^{-2}$ & $1.6 \times 10^{-2}$ & \\
\hline 47, after & $4.7 \times 10^{-2}$ & $4.3 \times 10^{-2}$ & \multirow{2}{*}{$5.4 \times 10^{-2}$} & $1.8 \times 10^{-2}$ & $1.6 \times 10^{-2}$ & \multirow{2}{*}{$2.1 \times 10^{-2}$} \\
\hline 47 , before & $4.1 \times 10^{-2}$ & $4.6 \times 10^{-2}$ & & $1.6 \times 10^{-2}$ & $1.8 \times 10^{-2}$ & \\
\hline
\end{tabular}


Table 7 External effective dose conversion factor $((\mu \mathrm{Sy} / \mathrm{y})$ per $(\mathrm{Bq} / \mathrm{g}))$ for worker and user calculated by MCNP5 code (broad-leaf trees)

\begin{tabular}{|c|c|c|c|c|c|c|}
\hline \multirow{2}{*}{$\begin{array}{c}\text { Year after } \\
\text { planting, } \\
\text { Thinning or } \\
\text { non-thinning }\end{array}$} & \multicolumn{3}{|c|}{${ }^{134} \mathrm{Cs}$} & \multicolumn{3}{|c|}{${ }^{137} \mathrm{Cs}$} \\
\hline & Trees & Thinned trees & $\begin{array}{c}\text { Organic } \\
\text { deposit }\end{array}$ & Trees & Thinned trees & $\begin{array}{l}\text { Organic } \\
\text { deposit }\end{array}$ \\
\hline 2 & $1.5 \times 10^{-3}$ & - & - & $5.8 \times 10^{-4}$ & - & - \\
\hline 9 & $8.6 \times 10^{-3}$ & - & $1.6 \times 10^{-2}$ & $3.3 \times 10^{-3}$ & - & $6.4 \times 10^{-3}$ \\
\hline 19 & $2.1 \times 10^{-2}$ & - & $4.0 \times 10^{-2}$ & $8.0 \times 10^{-3}$ & - & $1.6 \times 10^{-2}$ \\
\hline 29 & $3.9 \times 10^{-2}$ & - & $6.4 \times 10^{-2}$ & $1.5 \times 10^{-2}$ & - & $2.5 \times 10^{-2}$ \\
\hline 39 & $5.2 \times 10^{-2}$ & - & $8.7 \times 10^{-2}$ & $2.0 \times 10^{-2}$ & - & $3.4 \times 10^{-2}$ \\
\hline 49 , non-thinning & $6.6 \times 10^{-2}$ & - & \multirow{2}{*}{$1.1 \times 10^{-1}$} & $2.5 \times 10^{-2}$ & - & \multirow{2}{*}{$4.3 \times 10^{-2}$} \\
\hline 49, thinning & $5.1 \times 10^{-2}$ & $2.3 \times 10^{-2}$ & & $1.9 \times 10^{-2}$ & $8.8 \times 10^{-3}$ & \\
\hline 59, non-thinning & $8.1 \times 10^{-2}$ & - & \multirow{2}{*}{$1.3 \times 10^{-1}$} & $3.1 \times 10^{-2}$ & - & \multirow{2}{*}{$5.2 \times 10^{-2}$} \\
\hline 59 , thinning & $6.5 \times 10^{-2}$ & $2.3 \times 10^{-2}$ & & $2.5 \times 10^{-2}$ & $8.8 \times 10^{-3}$ & \\
\hline 69 , non-thinning & $1.0 \times 10^{-1}$ & - & \multirow{2}{*}{$1.6 \times 10^{-1}$} & $4.0 \times 10^{-2}$ & - & \multirow{2}{*}{$6.1 \times 10^{-2}$} \\
\hline 69 , thinning & $7.9 \times 10^{-2}$ & $2.3 \times 10^{-2}$ & & $3.0 \times 10^{-2}$ & $8.8 \times 10^{-32}$ & \\
\hline 79, non-thinning & $1.1 \times 10^{-1}$ & - & \multirow{2}{*}{$1.8 \times 10^{-1}$} & $4.4 \times 10^{-2}$ & - & \multirow{2}{*}{$7.0 \times 10^{-2}$} \\
\hline 79 , thinning & $1.0 \times 10^{-1}$ & $2.3 \times 10^{-2}$ & & $4.0 \times 10^{-2}$ & $8.8 \times 10^{-3}$ & \\
\hline
\end{tabular}

Table 8 External effective dose conversion factor $((\mu \mathrm{Sy} / \mathrm{y})$ per $(\mathrm{Bq} / \mathrm{g}))$ for members of public residing near the land reclamation site calculated by MCNP5 code (broad-leaf trees)

\begin{tabular}{|c|c|c|c|c|c|c|}
\hline \multirow{2}{*}{$\begin{array}{l}\text { Year after } \\
\text { planting, } \\
\text { Thinning or } \\
\text { non-thinning }\end{array}$} & \multicolumn{3}{|c|}{${ }^{134} \mathrm{Cs}$} & \multicolumn{3}{|c|}{${ }^{137} \mathrm{Cs}$} \\
\hline & Trees & Thinned trees & $\begin{array}{l}\text { Organic } \\
\text { deposit }\end{array}$ & Trees & Thinned trees & $\begin{array}{l}\text { Organic } \\
\text { deposit }\end{array}$ \\
\hline 2 & $6.0 \times 10^{-4}$ & - & - & $2.3 \times 10^{-4}$ & - & - \\
\hline 9 & $3.5 \times 10^{-3}$ & - & $6.3 \times 10^{-3}$ & $1.4 \times 10^{-3}$ & - & $2.4 \times 10^{-3}$ \\
\hline 19 & $9.3 \times 10^{-3}$ & - & $1.5 \times 10^{-2}$ & $3.5 \times 10^{-3}$ & - & $5.9 \times 10^{-3}$ \\
\hline 29 & $1.6 \times 10^{-2}$ & - & $2.4 \times 10^{-2}$ & $6.1 \times 10^{-3}$ & - & $9.4 \times 10^{-3}$ \\
\hline 39 & $2.3 \times 10^{-2}$ & - & $3.3 \times 10^{-2}$ & $8.8 \times 10^{-3}$ & - & $1.3 \times 10^{-2}$ \\
\hline 49, non-thinning & $3.1 \times 10^{-2}$ & - & \multirow{2}{*}{$4.3 \times 10^{-2}$} & $1.2 \times 10^{-2}$ & - & \multirow{2}{*}{$1.6 \times 10^{-2}$} \\
\hline 49, thinning & $2.4 \times 10^{-2}$ & $8.8 \times 10^{-3}$ & & $9.0 \times 10^{-3}$ & $3.4 \times 10^{-3}$ & \\
\hline 59, non-thinning & $3.9 \times 10^{-2}$ & - & \multirow{2}{*}{$5.2 \times 10^{-2}$} & $1.5 \times 10^{-2}$ & - & \multirow{2}{*}{$2.0 \times 10^{-2}$} \\
\hline 59, thinning & $3.1 \times 10^{-2}$ & $8.8 \times 10^{-3}$ & & $1.2 \times 10^{-2}$ & $3.4 \times 10^{-3}$ & \\
\hline 69, non-thinning & $4.7 \times 10^{-2}$ & - & \multirow{2}{*}{$6.1 \times 10^{-2}$} & $1.8 \times 10^{-2}$ & - & \multirow{2}{*}{$2.3 \times 10^{-2}$} \\
\hline 69, thinning & $3.9 \times 10^{-2}$ & $8.8 \times 10^{-3}$ & & $1.5 \times 10^{-2}$ & $3.4 \times 10^{-32}$ & \\
\hline 79, non-thinning & $5.3 \times 10^{-2}$ & - & \multirow{2}{*}{$7.0 \times 10^{-2}$} & $2.0 \times 10^{-2}$ & - & \multirow{2}{*}{$2.7 \times 10^{-2}$} \\
\hline 79, thinning & $4.6 \times 10^{-2}$ & $8.8 \times 10^{-3}$ & & $1.8 \times 10^{-2}$ & $3.4 \times 10^{-3}$ & \\
\hline
\end{tabular}



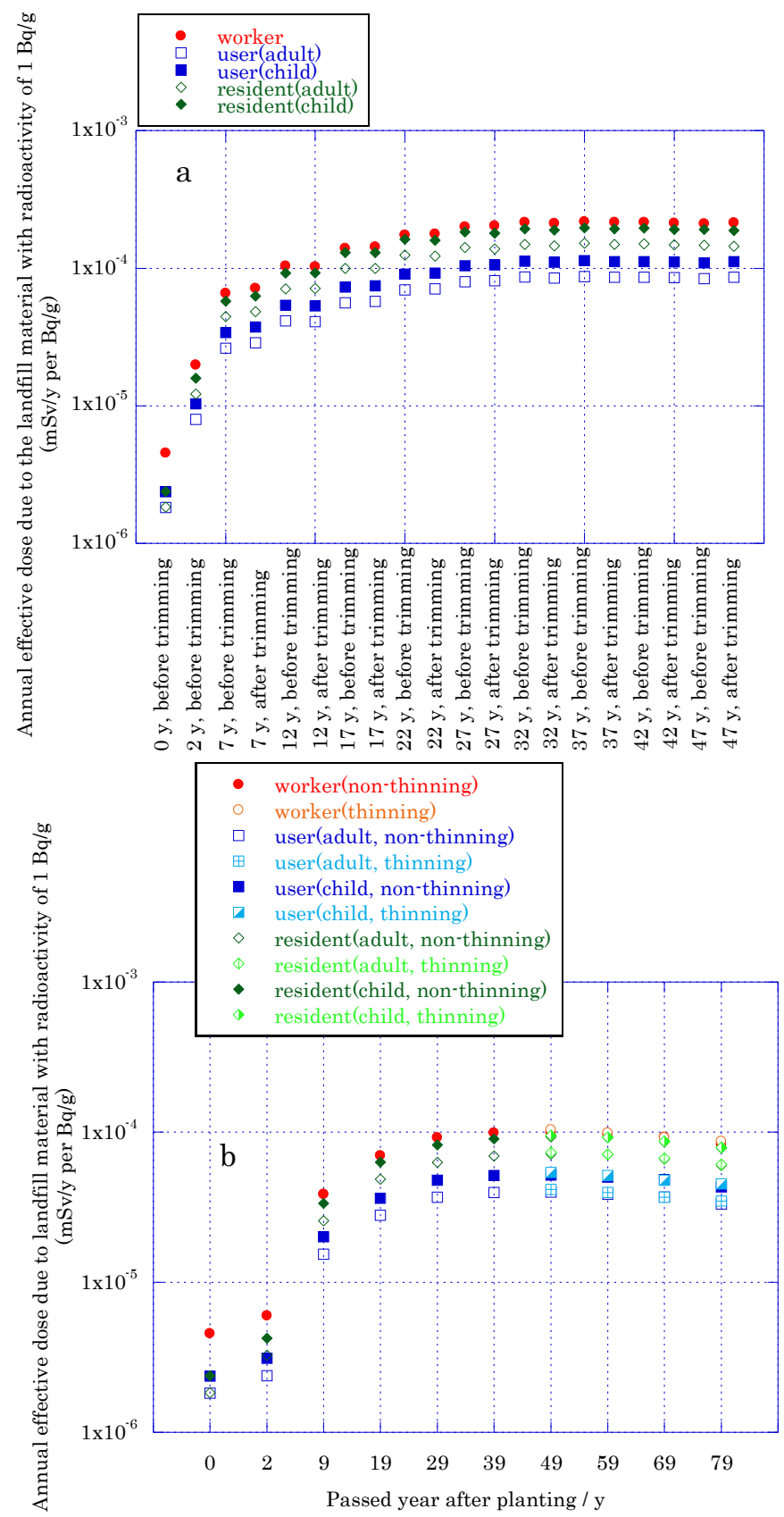

Fig. 2 Time change of annual effective dose due to landfill material with radioactivity of $1 \mathrm{~Bq} / \mathrm{g}$ for a: coniferous tree and $\mathrm{b}$ : broad-leaf tree 
The evaluation results during transportation are shown in Fig. 3. Although 4 cases were considered as shown in Table 1, transportation process is the same in 4 cases. The highest annual effective dose due to the recycling material with radioactivity of $1 \mathrm{~Bq} / \mathrm{g}$ in this process was due to external exposure of transportation workers, and its magnitude was $2.3 \times 10^{-2} \mathrm{mSv} / \mathrm{y}$ per $\mathrm{Bq} / \mathrm{g}$.

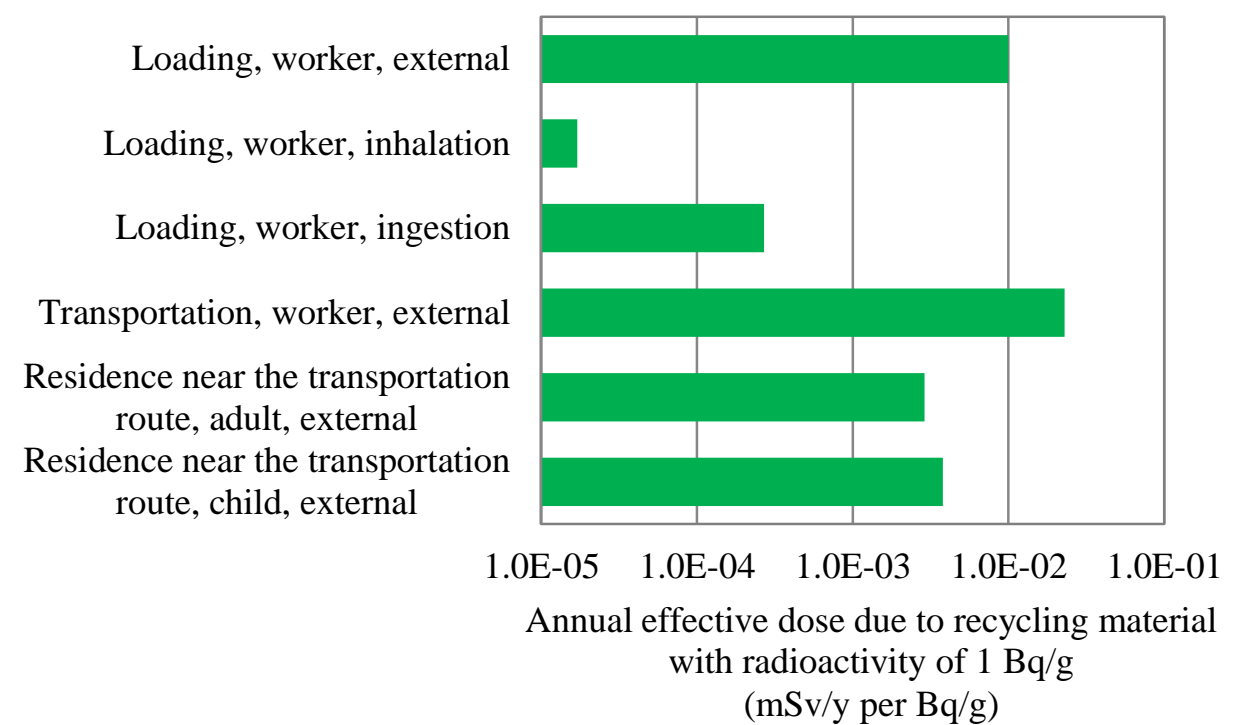

Fig. 3 Annual effective dose due to landfill material with radioactivity of $1 \mathrm{~Bq} / \mathrm{g}$ for transportation scenario (No.

1-6)

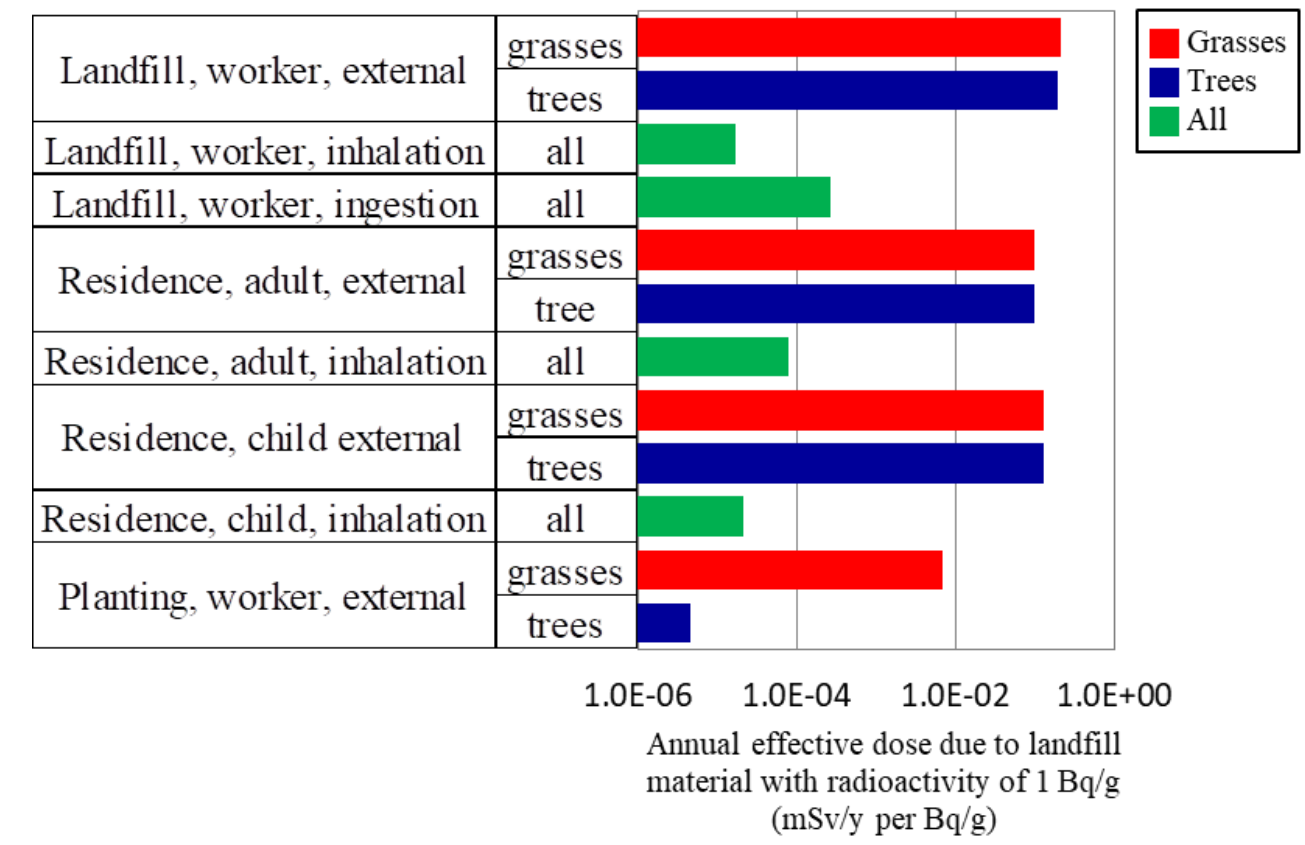

Fig. 4 Annual effective dose due to landfill material with radioactivity of $1 \mathrm{~Bq} / \mathrm{g}$ for construction scenario (No.7-15)

The evaluation results during construction are summarized in Fig.4.

Although the quantity of the landfill material for revegetation with grass was greater than that for revegetation with trees, similar results for external exposure pathways were obtained in both cases when the landfill materials were uncovered. In contrast, the result of the external exposure pathway for revegetation with grass was approximately three orders of magnitude higher than that for revegetation with trees when the surface was covered with non-contaminated soil. This indicates that the external exposure dose is significantly affected by the depth of the cover soil. 
The pathway with the highest annual effective dose due to the landfill material with radioactivity of $1 \mathrm{~Bq} / \mathrm{g}$ was the external exposure pathway for the landfill workers; 0.21 and $0.20 \mathrm{mSv} / \mathrm{y}$ per Bq/g for revegetation with grass and with trees, respectively. The inhalation and ingestion pathways resulted in lower annual effective doses due to the landfill material with radioactivity of $1 \mathrm{~Bq} / \mathrm{g}$ compared to the external pathway in the same scenario. Although the breathing rate $\left(1.2 \mathrm{~m}^{3} / \mathrm{h}\right.$, [ICRP Publ.23]) and the internal dose coefficient for the inhalation of the workers $\left(9.6 \times 10^{-3}\right.$ for ${ }^{134} \mathrm{Cs}$ and $6.7 \times 10^{-3}$ for ${ }^{134} \mathrm{Cs}$, respectively [ICRP Publ.68]) were higher than those for members of the public residing near the revegetated areas $\left(0.96 \mathrm{~m}^{3} / \mathrm{h}\right.$ [ICRP Publ. 23], $6.6 \times 10^{-3}$ for ${ }^{134} \mathrm{Cs}$, and $4.6 \times 10^{-3}$ for ${ }^{134} \mathrm{Cs}$, respectively, for an adult [ICRP Publ. 72], and $0.22 \mathrm{~m}^{3} / \mathrm{h}$ [IAEA Safety Reports Series No.44], $7.3 \times 10^{-3}$ for ${ }^{134} \mathrm{Cs}$ and $5.4 \times 10^{-3}$ for ${ }^{134} \mathrm{Cs}$, respectively, for a child [ICRP Publ. 72]), the annual exposure duration of members of the public residing near the revegetated area $(8760 \mathrm{~h} / \mathrm{y})$ was longer than that of a worker $(1000 \mathrm{~h} / \mathrm{y})$, resulting in the higher inhalation exposure of residents. For the safety side evaluation, the same air concentration of contaminated dust particles $5.0 \times 10^{-4} \mathrm{~g} / \mathrm{m}^{3}$ [NUREG/CR-3585] was used for a worker and a resident. The installation of a dust-proof wall was considered to decrease the dust concentration for the public.

The evaluation results obtained during serving of the area are summarized in Fig. 5. The order of the evaluation results for external pathways during serving of the area was grass, coniferous trees, broad-leaf trees (thinning), and broad-leaf trees (non-thinning). The calculated external effective dose conversion factors for the landfill material were $1.6 \times 10^{-2}$ and $5.5 \times 10^{-3}$ for ${ }^{134} \mathrm{Cs}$ and ${ }^{137} \mathrm{Cs}$, respectively, for the grass case, and $1.4 \times 10^{-5}$ and $3.3 \times 10^{-6}$ for ${ }^{134} \mathrm{Cs}$ and ${ }^{137} \mathrm{Cs}$, respectively, for tree cases. Although trees became radioactive and showed higher effective dose conversion factors as shown in Tables 5-8, the amount of radiocesium absorbed by the trees was less than that remaining in the landfill material, as calculated by the transfer factor 0.0055 . Consequently, the grass case showed a higher annual effective dose due to the landfill material with radioactivity of $1 \mathrm{~Bq} / \mathrm{g}$ compared to the tree cases, which indicates that the depth of the cover soil is more crucial in decreasing the external exposure doses. The higher evaluation results for coniferous trees than those for broad-leaf trees can be ascribed to the larger timber volume of coniferous trees. During serving of the area, inhalation exposure due to dust from tree material was assumed for a worker and user in the forest. However, the exposure dose due to inhalation was lower than that due to external exposure.

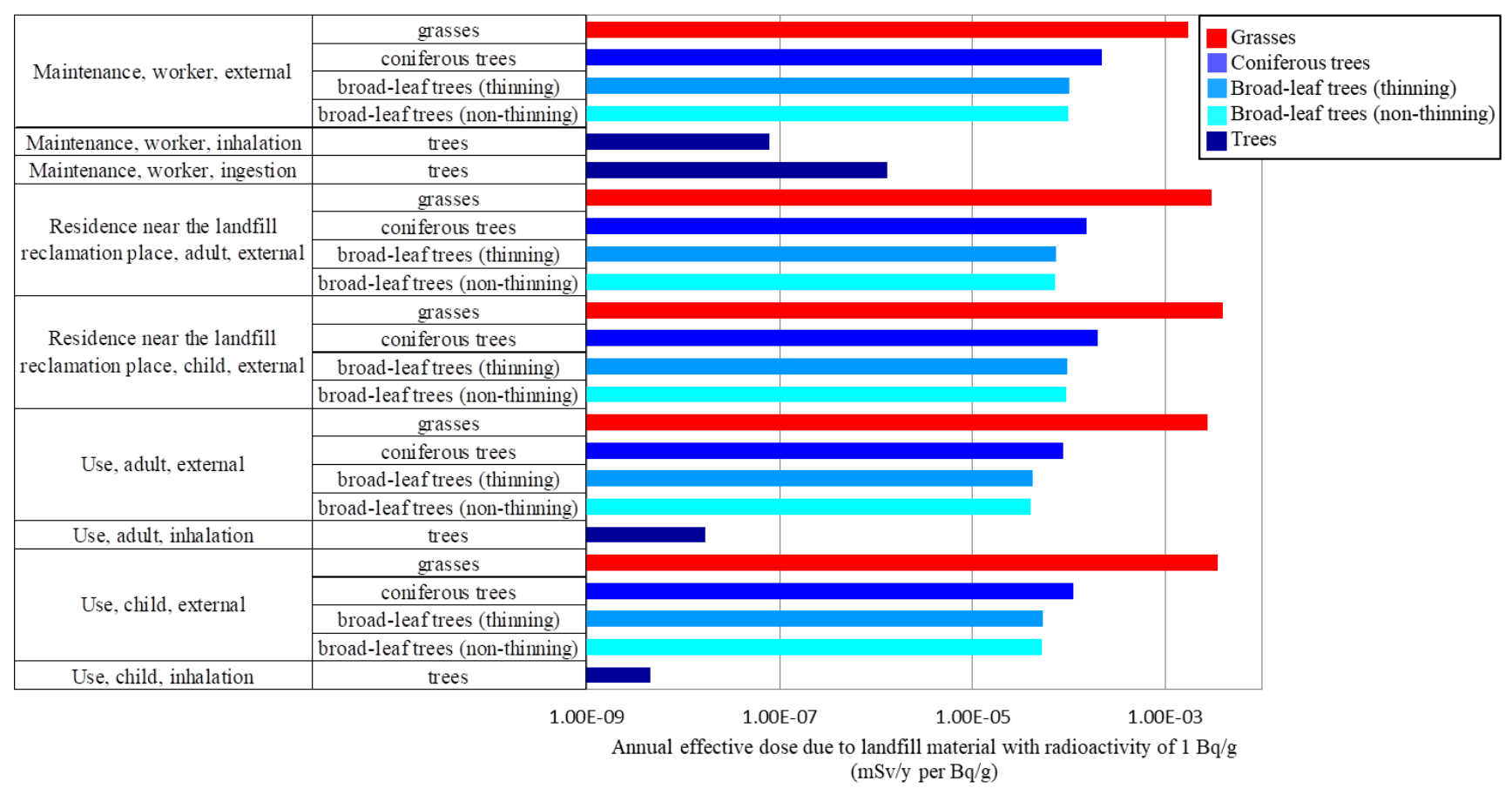

Fig. 5 Annual effective dose due to landfill material with radioactivity of $1 \mathrm{~Bq} / \mathrm{g}$ for in the service scenario (No.16-29)

\subsection{Dose estimation of groundwater migration scenario}

The evaluation results obtained for the groundwater migration are summarized in Fig. 6. The annual effective dose 
due to landfill material with radioactivity of $1 \mathrm{~Bq} / \mathrm{g}$ was calculated for ${ }^{134} \mathrm{Cs}$ and ${ }^{137} \mathrm{Cs}$ up to $100 \mathrm{y}$ later and the each maximum value was used for the evaluation. Although the amount of landfill material for the grass case was larger than that for the tree cases, comparable results were obtained for the grass and tree cases. The highest annual effective dose due to the landfill material with radioactivity of $1 \mathrm{~Bq} / \mathrm{g}$ in the groundwater migration case was obtained for the consumption of crops by adults. Because the quantity of intake for an adult is greater than that for a child, the exposure doses related to consumption for an adult were higher than those for a child.

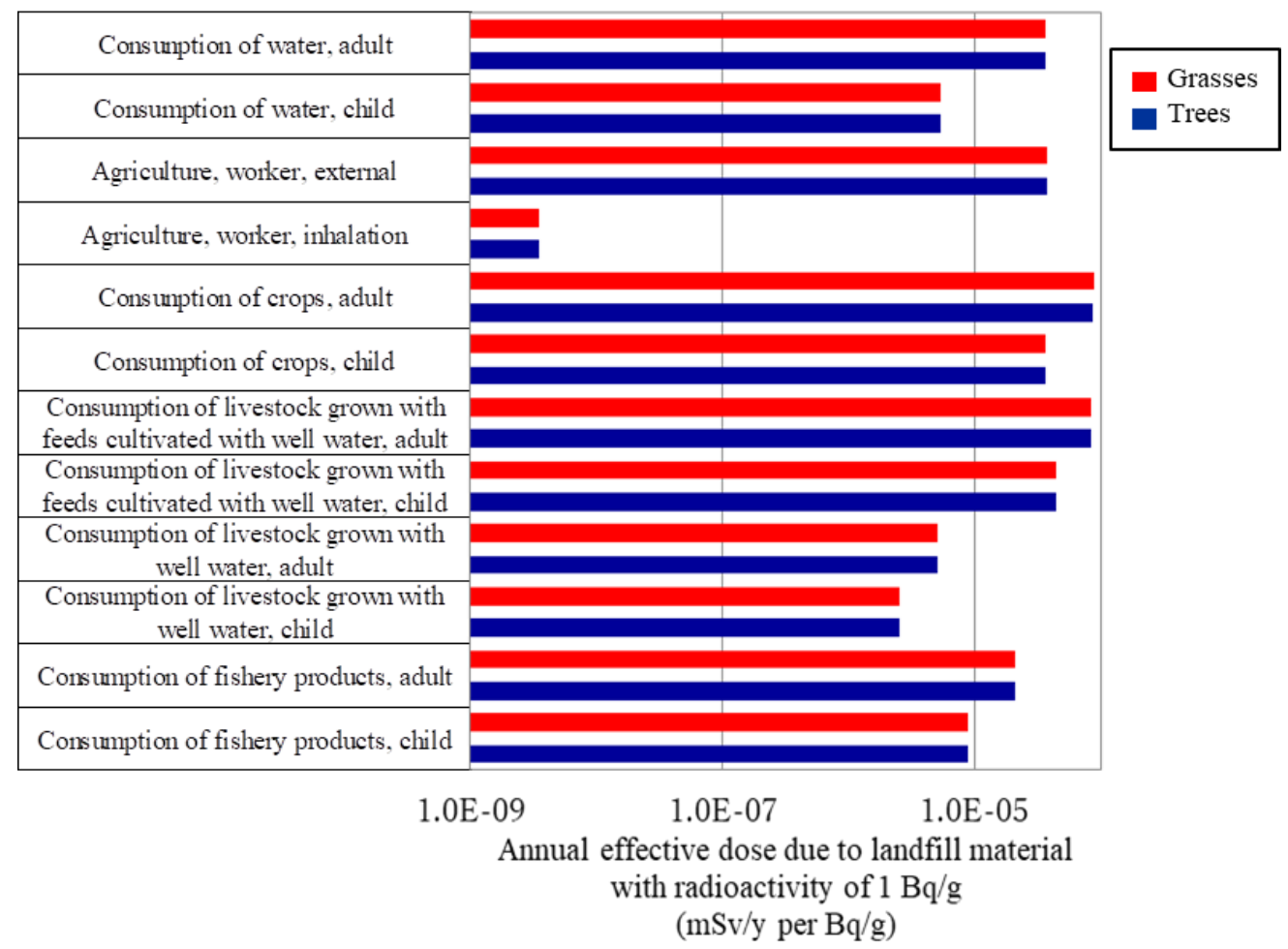

Fig. 6 Annual effective dose due to landfill material with radioactivity of $1 \mathrm{~Bq} / \mathrm{g}$ for groundwater migration scenario (No.30-40)

\subsection{Derivation of concentration level of recycled material}

Because MOE has a policy where the additional effective dose must be lower than $1 \mathrm{mSv} / \mathrm{y}$, the landfill material concentrations equivalent to $1 \mathrm{mSv} / \mathrm{y}$ were derived from the annual effective doses due to the landfill material with radioactivity of $1 \mathrm{~Bq} / \mathrm{g}$. The critical pathway, that is, the pathway with the highest annual effective dose due to the landfill material with radioactivity of $1 \mathrm{~Bq} / \mathrm{g}$, was external exposure of the landfill worker in all cases, and the values were 0.21 and 0.20 for revegetation with grass and trees, respectively. It was determined that the landfill material concentration equivalent to $1 \mathrm{mSv} / \mathrm{y}$ for the critical pathway, $4900 \mathrm{~Bq} / \mathrm{kg}$, should be the limiting radioactivity concentration of the landfill material to be recycled. This concentration is far lower than the case of disposal at the existing controlled disposal site, $100000 \mathrm{~Bq} / \mathrm{kg}$ or less because the land reclamation site was served for public and extra treatment such as seepage control and leachate treatment were not conducted for recycled soil.

\subsection{Construction condition to decrease exposure dose lower than $10 \mu \mathrm{Sv} / \mathrm{y}$ for public}

The pathway with the highest annual effective doses due to the landfill material with radioactivity of $1 \mathrm{~Bq} / \mathrm{g}$ to the public during serving the area was the external exposure of residents near the landfill site for child, in the example of revegetation with grasses. When the concentration of the landfill material was $4000 \mathrm{~Bq} / \mathrm{kg}$, increased to $4900 \mathrm{~Bq} / \mathrm{kg}$ to err on the side of caution, the annual effective dose to a child residing near the landfill reclamation site would be 16 $\mu \mathrm{Sv} / \mathrm{y}$. It was proposed that the annual effective dose level for which no protective measures from radiation hazards are required is $10 \mu \mathrm{Sv} / \mathrm{y}$. Therefore, a design to decrease the annual exposure dose to lower than $10 \mu \mathrm{Sv} / \mathrm{y}$ was examined. Figure 7 shows the dependence of the annual exposure dose of a child residing near the landfill reclamation site on the thickness of the cover soil. The annual exposure dose exponentially decreased with an increase in the thickness of the 
cover soil. When the thickness of the cover soil was more than $40 \mathrm{~cm}$, the annual exposure dose was lower than 10 $\mu \mathrm{Sv} / \mathrm{y}$.

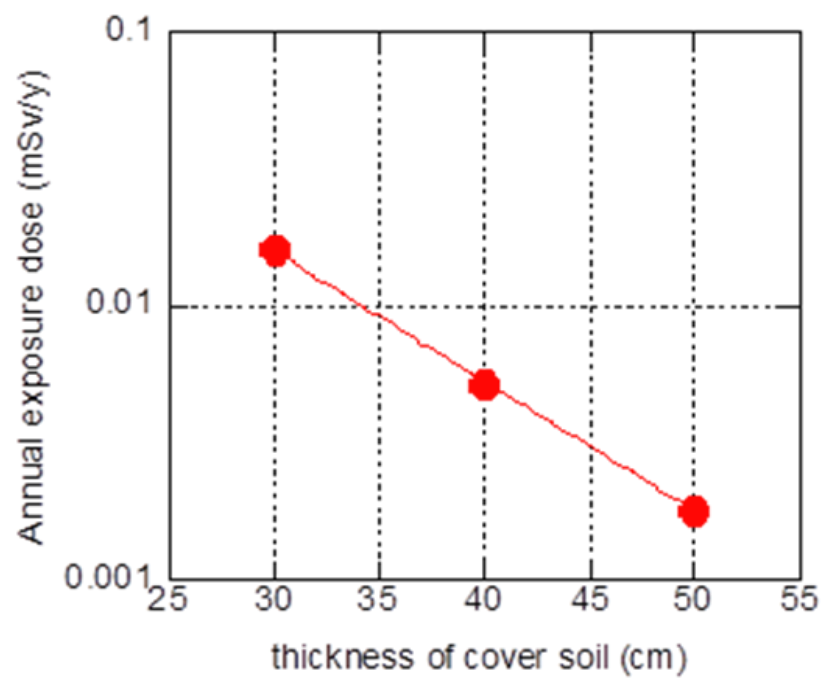

Fig. 7 Dependence of annual exposure dose on thickness of cover soil.

\subsection{Dose estimation of disaster scenario}

The evaluation results obtained for tsunamis, fires, and intense heavy rain are summarized in Fig. 8. Evaluations for tsunamis and intense heavy rain were carried out considering only grass planting because the quantity of landfill material was the highest in this case. In contrast, the evaluation for fires was carried out considering revegetation with coniferous trees because the quantity of tree biomass was the highest in this case.

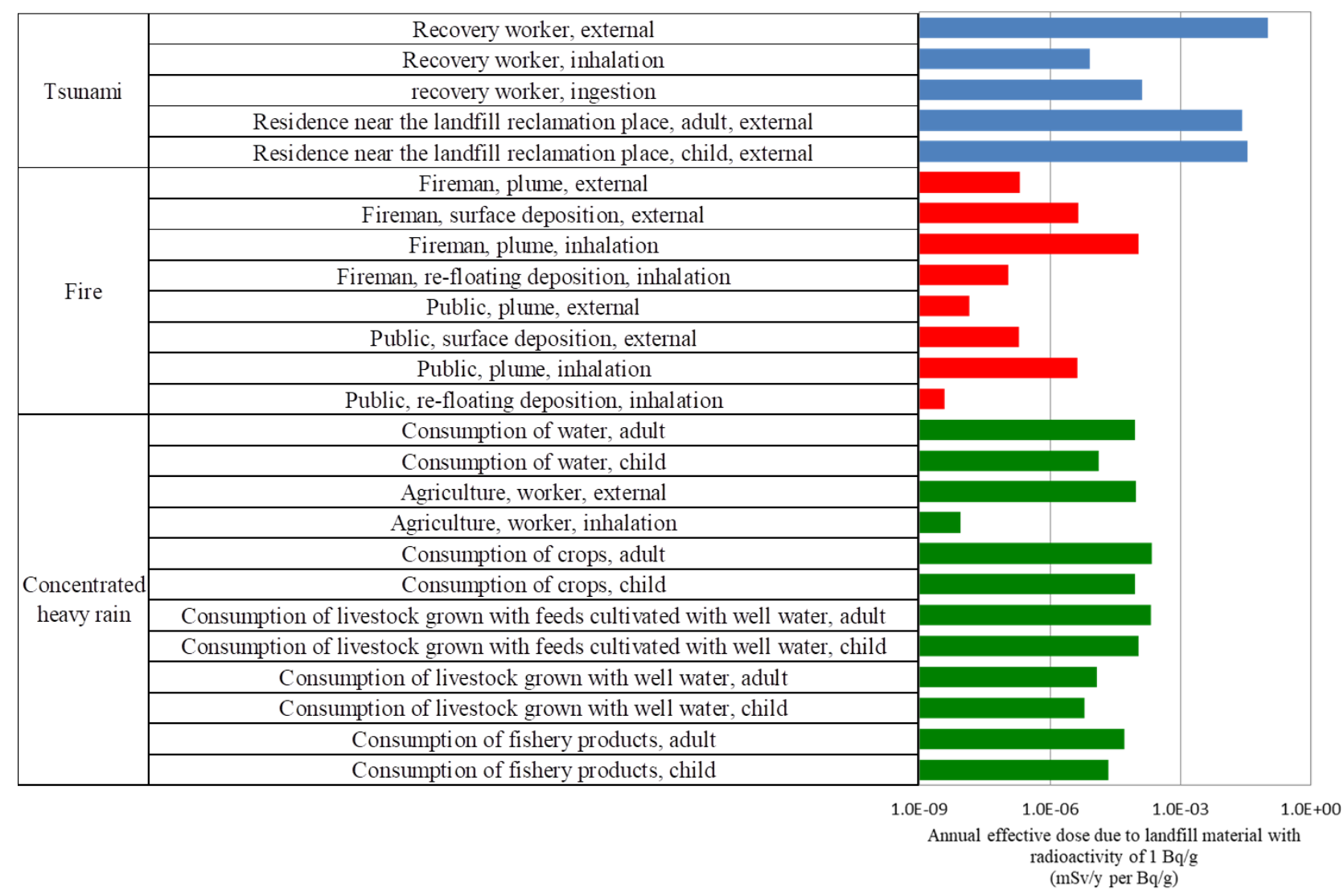

Fig. 8 Evaluation results for natural disaster circumstances 
The critical pathways for tsunamis, fires, and intense heavy rain were the external exposure of relief workers, plume inhalation by firefighters, and consumption of crops by adults, respectively. The concentrations equivalent to 1 $\mathrm{mSv} / \mathrm{y}$ for these critical pathways were $9.8 \times 10^{3}, 9.3 \times 10^{6}$, and $4.7 \times 10^{6} \mathrm{~Bq} / \mathrm{kg}$, respectively. These values are higher than the limiting radioactivity concentration of recycled soil, which is $4.9 \times 10^{3} \mathrm{~Bq} / \mathrm{kg}$, obtained under normal circumstances. This means that exposure doses during disasters were lower than $1 \mathrm{mSv} / \mathrm{y}$ when the recycled soil was used.

\section{Conclusions}

Exposure doses of recycling of the removed soil were evaluated from the viewpoint of future application of the soil for landfill reclamation. The limiting radioactivity concentration of recycled soil was set to $4900 \mathrm{~Bq} / \mathrm{kg}$. A 40-cm-thick layer of cover soil was applied to limit the exposure dose to less than $10 \mu \mathrm{Sv} / \mathrm{y}$ for the public. Furthermore, the exposure doses during disasters, such as tsunamis, fires and intense heavy rain were simulated to confirm that they were lower than $1 \mathrm{mSv} / \mathrm{y}$.

\section{Acknowledgments}

This research was funded by the Ministry of Environment, Japan.

\section{References}

Henmi, K. Yamaguchi, T. Takeda, S. Kimura, H., Analysis on the effect of forest decontamination on reducing the air dose rate using the three-dimensional transport code MCNP, Journal of Nuclear Fuel Cycle and Environment, Vol.24, No.1, (2017), pp.3-14.

IAEA, Exemption of Radiation Sources and Practices from Regulatory Control: Interim Report, IAEA-TECDOC-401, (1987).

IAEA, Derivation of Activity Concentration Values for Exclusion, Exemption and Clearance, Safety Reports Series, No.44, (2005).

IAEA, Principles of Radioactive Waste Management Safety Fundamentals, IAEA S.S. No.111-P1.1, (1995).

ICRP, Report on the Task Group on Reference Man, ICRP Publ. No.23, (1975).

Iharakawa, K. Nakagawa, H. The amounts of litter fall, contained carbon, contained nitrogen in conifer plantation, Gifu Shinrinho,Vol.31, (2002), pp.7-12.

Ito, K. Miyahara, H. Ujiie, T. Takeshima, T. Yokoyama, S. Nakata, K. Nagano, T. Sato, T. Hatta, T. and Yamada, H., Practical Approach to Decontamination of Radioactive Cesium-Contaminated Matter in Agricultural Region by Improved Wet Classi^cation and Use of Geomaterials, Nihongensiryokugakkaiwabunshi, Vol.11, No.4, (2012), pp.255-271. (in Japanese).

Japan Atomic Energy Agency, Report for "Research for creation of guidelines for decontamination of Fukushima prefecture related to Fukushima Daiichi Nuclear Power Station”, (2012). https://fukushima.jaea.go.jp/fukushima/result/entry03.html (last visited at Oct. 11, 2019).

Japanese groundwater editorial board, Japanese groundwater, 1979, Chikyusya, Japan.

K. Tagami and S. Uchida, Can elemental composition data of crop leaves be used to estimate radionuclide transfer to tree leaves?, Radiation and Environmental Biophysics, Vol.49, No.4, (2010), pp. 583-590.

Kawabara, T. In reference to litter fall and its decomposition, Bull. For \& For. Prod. Res. Inst, No.334, (1985), pp.21-52.

Miyagi prefecture, guidelines concerning fill materials associated with east Japan earthquake restoration and reconstruction (plan), (https://www.pref.miyagi.jp/uploaded/attachment/118000. pdf)

Sakamoto, Y., et al., 1990, QAD-CGGP2 and G33-GP2 : revised versions of QAD-CGGP and G33-GP, JAERI-M90-110

Sawaguchi, T, Takeda, S. Kimura, H. Tanaka, T., Estimation of doses from radioactivity contaminated disaster wastes reused for pavements, Jpn. J. Health Phys., Vol. 50(1), (2015), pp. 36-49.

The Ministry of Environment of Japan, Technology development strategy for volume reduction \& recycling of 
decontamination soil,

http://josen.env.go.jp/chukanchozou/facility/effort/investigative_commission/pdf/investigative_commission_text.p df

Takeda, S., Kanno, M. Sasaki, T. Minase, N. Kimura, H., Development of PASCLR code system version 2 to derive clearance levels of uranium and trans uranium wastes, JAEA-Data/Code 2006-003 (2006).

Takeda, S., Sawaguchi, T. Kimura, H., Dose estimate in treatment and disposal of contaminated materials due to the accident at the Fukushima Nuclear Power Plant, Master. Res. Soc. Symp. Proc., Vol. 1665, (2014), pp. 103-109.

Takai, S, Sawaguchi, T. Takeda, S., Dose estimation in Recycling of decontamination soil due to Fukushima NPS accident as coastal levees-18138, Proc. of WM2018 Conference, March 18-22, 2018, Phoenix, Arizona, USA.

Tohoku regional forest office, Fifth national forests management plan (2015) http://www.rinya.maff.go.jp/tohoku/policy/business/management/keikaku/tikan_jissi_keikakusyo.html

Tsukada, H. Takeda, A. Hisamatsu, S. Inaba, J., Concentration and specific activity of fallout 137Cs in extracted and particle-size fractions of cultivated soils, J. Environ. Radioact. Vol.99, (2008), pp.875-881.

Watanabe, M. and Tagawa, A., Report for "Decontamination Pilot Projects for the environmental remediation of evacuation areas contaminated with radioactive materials discharged from the Fukushima Daiichi Nuclear Power Plant accident; Decontamination Technology Demonstrations Projects" (Contract research), JAEA-Review-2013-053, (2013) (in Japanese).

X-5 Monte carlo team, 1987, MCNP-A general monte carlo n-particle transport code, version 5, LA-UR-03-1987. 